\title{
Nutritional Status and Quality of Life in Breast Cancer Patients in Karawaci General Hospital
}

\author{
ANDREE KURNIAWAN, NATA PRATAMA HARDJO LUGITO \\ Internal Medicine, School of Medicine, Pelita Harapan University \\ Diterima: 9 November 2015; Direview: 12 November 2015; Disetujui: 4 Desember 2015
}

\author{
KORESPONDENSI: \\ dr. Andree Kurniawan, SpPD \\ Internal Medicine, \\ Faculty of Medicine, \\ University of Pelita Harapan, \\ Siloam General Hospital, \\ Jl. Boulavard Jendral \\ Sudirman \\ (near Siloam hospital), \\ Karawaci, Tangerang, \\ Banten 15811 Indonesia \\ Phone: \\ +62-21-54210130 Ext: \\ 3411 \\ Facsimile: \\ +62-21- 54210133 \\ Email: \\ andree.kurniawan@uph.edu, \\ a125ee@yahoo.com
}

\begin{abstract}
Cancer is related to a deterioration of nutritional status and quality of life (Qol), but the extent of these conditions in patients with breast cancer has not been studied well. Malnutrition is prevalent among cancer patients and maybe correlated with altered quality of life. The aim of this study is to evaluate the association of QoL and nutritional status after breast cancer diagnosed. Nutritional status was evaluated with Patient Generated — Subjective Global Assessment and QoL using Short form 36 (SF-36) and also with the specific module for breast cancer patients. A consecutive sample of twenty two patients diagnosed with breast cancer was evaluated. The associations of $Q o L$ with stadium and nutrition status were evaluated using T-test analysis. The mean of body mass index was $21.3 \mathrm{~kg} / \mathrm{m}^{2}$. Fifty percent patient have menopause. Most patients were stage II (77.3\%), the others stage III (18.2\%) and stage I (4.5\%). Sixty eight point two percent had risk of malnutrition. The stadium of tumor was significantly related to physical functioning $(p<0.000)$, physical limitation $(p<0.024)$, emotional limitation $(p<0.013)$, well-being $(p<0.020)$, health changes $(p<0.010)$. The status of nutrition was significantly related to physical functioning $(p<0.001)$, loss of energy $(p<0.010)$ and general health $(p<0.005)$. For Conclusion, the status of nutrition breast cancer patients were related to QoL especially physical functioning, loss of energy and general health after they were diagnosed.
\end{abstract}

Keyword: breast cancer; Indonesian; nutritional status; quality of life

\section{ABSTRAK}

Kanker sangat terkait dengan perburukan status nutrisi dan kualitas hidup. Namun demikian, belum banyak studi yang yang melaporkan masalah nutrisi dan kulitas hidup pada kanker payudara. Malnutrisi sering ditemukan pada kanker dan mungkin terkait dengan perubahan kulaitas hidup. Tujuan penelitian ini adalah untuk mengevaluasi hubungan antara kualitas hidup dengan status nutrisi setelah kanker payudara terdiagnosis. Evaluasi status nutrisi dilakukan dengan Patient Generated — Subjective Global Assessment dan kualitas hidup dengan Short form 36 (SF-36) serta karakteristik pada kanker payudara. Sampel diambil dengan teknik konsekutif terhadap 22 pasien yang terdiagnosis kanker payudara. Hubungan kualitas hidup dengan stadium kanker dan status nutrisi dinilai menggunakan analisis T-test. Indeks massa tubuh rata-rata adalah $21,3 \mathrm{~kg} / \mathrm{m}^{2}$. Lima puluh pasien telah menopause. Terbanyak adalah stadium $2(77,3 \%)$, stadium $3(18,2 \%)$, dan stadium $1(4,5 \%)$. Enam puluh dua koma dua persen berisiko malnutrisi. Stadium tumor secara bermakna berhubungan dengan fungsi fisik $(p<0,000)$, keterbatasan fisik $(p<0,024)$, keterbatasan emosi $(p<0,013)$, rasa nyaman $(p<0,020)$, dan perubahan kesehatan $(p<0,000)$. Status nutrisi berhubungan secara bermakna dengan fungsi fisik $(p<0,001)$, kehilangan energi $(p<0,010)$, dan kesehatan secara umum $(p<0,005)$. Simpulan, status nutrisi pasien kanker payudara berhubungan dengan kualitas hidup, terutama fungsi fisik, kehilangan energi, status kesehatan umum setelah mereka terdiagnosis.

Kata Kunci: kanker payudara, Indonesia, status nutrisi, kualitas hidup 


\section{INTRODUCTION}

$\mathrm{B}^{\mathrm{r}}$ reast cancer is the most common cancer among women. In 2008, 23\% (1.38 million) of the total new cancer cases and 14\% (458.400) of total cancer deaths among females were associated with breast cancer. ${ }^{1,2}$ While the prevalence of breast cancer has been increased worldwide, the highest incidence has been reported in Asian countries. ${ }^{2,3}$ Breast cancer survival rates of women in Asia are approximately half of their Western counterparts. In Indonesia, breast cancer is still the most common cancer and the most important women's health issues.

Cancer is related to a deterioration of nutritional status and quality of life (Qol). ${ }^{4}$ Nutritional decline is typically accepted as a consequent of the course of treatment for cancer. Cancer alters metabolic and physiological aspects of patients' nutritional needs for carbohydrate, protein, fat, vitamins and minerals. On the other hand, nutritionally impacted symptoms (nausea, vomiting, loss of appetite, stomach pain, constipation, diarrhea, loss of taste, sore mouth and difficulty swallowing), which may result from a tumor itself or from side effects of treatment, have negative effects on energy and dietary intake and lead to increased risk of malnutrition. Dietary intake also played a role in prognosis of breast cancer and may modify the progression of disease. ${ }^{4,5}$

Quality of life is determined based on individual functional health status, level of pain, self-attribution, self- perception and quality of interaction with their surrounding environment. It is a multidimensional concept which addresses various areas related to physical, emotional, sexual and functioning. A systematic review demonstrated a strong association between nutritional status and health related quality of life in the cancer population. ${ }^{2}$

This study is the first to investigate the association between nutritional status and quality of life among breast cancer patients in our hospital after they were diagnosed.

\section{MATERIAL AND METHODE}

A cross-sectional study was conducted to examine the relationship between nutritional status and quality of life among Indonesian Breast cancer patients. This study was done in private general hospital in the west part of Jakarta, Indonesia using convenience sampling. Interview was carried out from January 2014 to December 2014 with breast cancer patients who come to inpatients ward Karawaci General Hospital.

Twenty two breast cancer patients were recruited through non-probability sampling. Women aged $>$ or $=18$ years, who were diagnosed with breast cancer was invited to participate. Only the patients who met the inclusion criteria and signed consent form were invited to join this study. All of the patients have got treatment for breast cancer based on National Comprehensive Cancer Network (NCCN). A set of questionnaires was used to obtain information from the subjects such as sociodemographic data, cancer stage, subject's functional status, nutritional status and quality of life. The nutritional status of patients was evaluated by anthropometric measurements and with Patient Generated - Subjective Global Assessment (PGSGA). The scoring of PG-SGA was classified into 3 categories A (well nourished), B (moderately malnourished), and C (severely malnourished). Quality of life was assessed using QoL using Short form 36 (SF-36) and also with the specific module for breast cancer patients. The scoring of SF-36 was counted using SF-36 software and classified if they had physical and mental health problems. Participants were also evaluated their performances status using Eastern Cooperative Oncology Group (ECOG) performances status. The associations of QoL with stadium and nutritional status were evaluated using T-test analysis.

\section{RESULT}

Demographic characteristics of breast cancer patients are described in Table 1. The mean age was $41 \pm 3.5$ year old. The mean of body mass index was $21.3 \mathrm{~kg} / \mathrm{m} 2$. There are no overweight and obese patients. Five patients were identified as underweight by using Body Mass Index (BMI). Fifty percent patient have menopause. Most patients were stage II (77.3\%), the others stage III (18.2\%) and stage I (4.5\%). Sixty eight point two percent had moderately malnourished. The stadium of tumor was significantly related to physical functioning $(\mathrm{p}<0.000)$, physical limitation $(p<0.024)$, emotional limitation $(p<0.013)$, wellbeing $(p<0.020)$, health changes $(p<0.010)$. The status of nutrition was significantly related to physical functioning ( $p<0.001)$, loss of energy ( $p$ $<0.010)$ and general health $(\mathrm{p}<0.005)$. 
Table 1: Demographic characteristic of breast cancer patients

\begin{tabular}{lll}
\hline Characteristics & & $(\mathrm{n}=22)$ \\
\hline Age & 3250 years & 12 \\
& 5161 years & 10 \\
Cancer stage & I & 1 \\
& $\|$ & 17 \\
ECOG & III & 4 \\
& 0 & 2 \\
& 1 & 15 \\
PG-SGA & 2 & 5 \\
& A & 4 \\
& B & 15 \\
BMI & C & 3 \\
& $<18.5$ & 5 \\
B. & 18.522 .9 & 17
\end{tabular}

BMl: Body Mass Index; ECOG: Eastern Co-operative Oncology Group: PG-SGA: Patient generated-Subjective Global Assessment

\section{DISCUSSION}

This cross-sectional study has been done to determine the association of nutritional status with quality of life in Indonesian breast cancer patients. Several study have been reported the relationship between nutritional status and quality of life in cancer patients as general. The patient method done in this study was different from study conducted in Malay. Lua and college conducted cross-sectional study in breast cancer patients receiving chemotherapy in Malay 2012 evaluating relationship between nutritional status and quality of life in breast cancer patients. According to the classification of BMI by WHO, There are no obese and overweight patients. This result was different from the study conducted in Malay, there was $70 \%$ breast cancer survivor patients were obese. ${ }^{4}$

Based on Patient-Generated Subjective global assessment (PG-SGA) method to assess nutritional status in this study, 18.1 percent patient were wellnourished, 68.2 percent of breast cancer patient were at risk of malnutrition, and 13.6 percent were moderately malnourished while severe malnourished not identified in this study. In the study conducted in Malay, there was no severe malnourished in breast cancer patients. ${ }^{4}$ However, breast cancer patient in Brazil had higher rate of mild and moderately malnourished (24\%) based on SGA tools. ${ }^{6}$

The relationship between nutritional status and quality of life in patients with cancer has been indicated. The contribution of nutritional status and quality of life in breast cancer patients has been revealed in several studies. Determining QoL in this study was using SF-36. The result of SF-36 was classified into physical and mental health. Physical health comprises physical functioning, role-physical, bodily pain, and general health. Mental health comprises vitality (loss of energy), social functioning, role-emotional and mental health. From our study, the status of nutrition was significantly related to physical functioning, loss of energy and general health, components of health related quality of life. Others study also found the similar result. Lua and college did a study to assess relation between nutrition status and health-related quality of life in breast cancer patients on chemotherapy. Body weight status has been shown to be important in QoL profile and suggested to evaluate nutritional assessment and support to cancer population especially breast cancer patients. Most patients reported had losing weight. ${ }^{4}$

From the Malay study there were significant associations with all functional and symptom scale except for social functioning and financial difficulty symptom scale. Therefore, survivors with better nutritional status had better functions and experienced less common symptoms, whereas malnourished survivors had lower physical, cognitive, and social performances and experienced greater symptoms. ${ }^{4}$ Other study also found that malnutrition was associated with a poorer quality of life and its other dimension, as patients with better nutritional status exhibited a better level of functioning. ${ }^{7-9}$

Dietary intake and trace element also had beneficial for the survivor of breast cancer patients. Mohammadi $S$ and college did a study from 100 Iranian breast cancer survivor and they found overall participants had an inadequate intake of vitamin $\mathrm{D}, \mathrm{E}$, iron and magnesium according to dietary reference intake (DRI) recommendations. Survivors with better nutritional status had better functioning scales and experienced fewer clinical symptoms. In this study we did not evaluate for adequacy intake of food and trace minerals. ${ }^{2}$

\section{CONCLUSION}

The status of nutrition breast cancer patients were related to QoL especially physical functioning, loss of energy and general health after they were diagnosed. 


\section{DISCLOSURE}

This abstract has been presented in Best of ASCO, Singapore, July 2015 as poster presentation

\section{REFERENCES}

1. Ferlay J, Shin HR, Bray F. Estimates of worldwide burden of cancer in 2008: GLOBOCAN 2008. Int I Cancer 2010;127:2893917

2. Mohammadi S, Sulaiman S, Koon PB, Amani R, Hosseini SM. Association of nutritional status with quality of life in breast cancer survivors. Asian Pac J Cancer Prev 2013;14(12):7749-55

3. Green M, Raina V. Epidemiology, screening and diagnosis of breast cancer in the Asia-Pacific region: current perspectives and important considerations. Asia Pac J Clin Oncol 2008;4:5-13

4. Lua Pl, Salihah NZ, Mazian N. Nutritional status and healthrelated quality of life of breast cancer patients on chemotherapy. Malays J Nutr 2012 Aug;18(2):173-84
5. Tong $\mathrm{H}$, Isenring E, Yates P. The prevalence of nutrition impact symptoms and their relationship to quality of life and clinical outcomes in medical oncology patients. Supportive care in Cancer 2009;17:83-90

6. Zorlini R, Akemi Abe Cairo A, Salete Costa Gurgel M. Nutritional status of patients with gynecologic and breast cancer. Nutricion Hospitalaria 2008;23:577-83

7. Vergara N, Montoya JE, Luna HG, Amparo JR, Luna GC. Quality of life and Nutritional status among cancer patients on chemotherapy. Oman Medical Journal (2013) vol. 28;4:270-4

8. Gupta D, Lis CG, Granick J. Malnutrition was associated with poor quality of life in colorectal cancer: a retrospective analysis. J Clin Epidemiol 2006;59:704-9

9. Persson C, Glimelius B. The relevance of weight loss for survival and quality of life in patients with advanced gastrointestinal cancer treated with palliative chemotherapy. Anticancer Res 2002;22:3661-8 